Supporting Information for:

\title{
Photodependent melting of unmodified DNA using a photosensitive intercalator: a new and generic tool for photoreversible assembly of DNA nanostructures at constant temperature
}

Anna Bergen, ${ }^{1,2,3}$ Sergii Rudiuk, ${ }^{1,2,3}$ Mathieu Morel, ${ }^{1,2,3}$ Thomas Le Saux, ${ }^{1,2,3}$ Heiko Ihmels, ${ }^{4}$ and Damien Baig|1,2,3,*

\footnotetext{
${ }^{1}$ Department of Chemistry, Ecole Normale Supérieure - PSL Research University, 24 rue Lhomond, 75005 Paris, France)

${ }^{2}$ Sorbonne Universités, UPMC Univ Paris 06, PASTEUR, 75005 Paris, France

${ }^{3}$ CNRS, UMR 8640 PASTEUR, 75005 Paris, France

${ }^{4}$ Department of Chemistry - Biology, University of Siegen, Adolf-Reichwein-Str. 2, 57068 Siegen, Germany
}

\section{Content}

1. Materials

p. 2

2. Methods

p. 3

3. Scheme S1: Synthesis of PGDs

p. 6

4. Figure S1: Thermal relaxation of PGDs

p. 9

5. Figure S2: Binding of AzoDiGua to double- and single-stranded oligonucleotides

p. 10

6. Figure S3: Fluorescence microscopy characterization of the Compaction of T4 DNA by AzoGua

7. Figure S4: Static light scattering of ct-DNA as a function of PGD concentration

8. Figure S5: Melting of Oligo1 and Oligo2 as a function of AzoDiGua:DNA ratio and illumination conditions

9. Figure S6: Control experiments for the photoreversible melting of Oligo3 


\section{1) Materials}

Calf Thymus DNA (ct-DNA type I, highly polymerized sodium salt; $\varepsilon=12824 \mathrm{~cm}^{-1} \mathrm{M}^{-1}$ ), oligonucleotides (salt free, Oligo1: $\varepsilon=10020 \mathrm{~cm}^{-1} \mathrm{M}^{-1}$, Oligo2: $\varepsilon=10460 \mathrm{~cm}^{-1} \mathrm{M}^{-1}$ ) and all the molecules used for the synthesis were purchased from Sigma. Bacteriophage T4DNA was from Wako Chemicals, Oligo3 was from Iba Gmbh, and the bisintercalator YOYO-1 was from Life Technologies. Deionized water (Millipore, $18 \mathrm{M} \Omega \cdot \mathrm{cm}$ ) was used for all experiments. 


\section{2) Methods}

UV spectroscopic kinetic studies. Absorption spectra for kinetic studies (Figure 2a-b, SI Figure S1) were recorded using a Synergy HT spectrophotometer from BioTek Instruments with the Gen5 acquisition software. For the trans-cis isomerization the samples $(200 \mu \mathrm{l}$ in a 96-microplate well, $d=6 \mathrm{~mm}$ ) were irradiated for $5 \mathrm{~s}$ with a UV lamp at $365 \mathrm{~nm}$ (Vilbert Lormat, $6 \mathrm{~W})$ in a distance of ca. $4-6 \mathrm{~cm}\left(0.35 \mathrm{~mW}^{\left.-\mathrm{cm}^{-2}\right)}\right.$ before recording the spectra from $200-550$ $\mathrm{nm}$, and the procedure was repeated until a photostationary state was reached. For the cistrans isomerization (thermal relaxation) the same sample was irradiated for 4 minutes and the spectra were taken every $15-30$ min for several hours in the dark at $26{ }^{\circ} \mathrm{C}$.

UV spectroscopic titrations. DNA titration experiments were performed with a Perkin Elmer Lambda 45 UV/VIS spectrometer. Before each experiment a baseline (Tris buffer) was recorded that was subtracted from the sample spectra. Experiments were performed in semimicro quartz cells $(d=10 \mathrm{~mm})$ at $200-600 \mathrm{~nm}$. To a solution of the PGD (50 $\mu \mathrm{M}$ in Tris buffer) subsequently DNA was added and after each addition a spectrum was recorded. To avoid dilution of the PGD by the addition of DNA, the DNA solution contained the same PGD concentration.

DNA thermal denaturation studies. For experiments that were performed under permanent UV irradiation, the DNA melting curves were recorded with Evolution Array (Thermo Scientific) UV-VIS spectrometer. For all other experiments Varian Cary 100 UV Bio Spectrophotometer equipped with a temperature controller was used. Samples were prepared by mixing Tris buffer $\left(c_{\text {final }}=10 \mathrm{mM}, \mathrm{pH} 7.4\right.$ ), water, PGD and DNA (ct-DNA: $c_{\text {final }}=40 \mu \mathrm{M}$; Oligos: $c_{\text {final }}=20 \mu \mathrm{M}$ in phosphate groups). For experiments with oligonucleotides, additional $\mathrm{NaCl}$ was added $\left(C_{\text {final }}=\right.$ 5 or $10 \mathrm{mM})$. The absorption at $260 \mathrm{~nm}$ was monitored in semi-micro quartz cells $(d=10 \mathrm{~mm})$ at different temperatures. Samples were heated from $20^{\circ} \mathrm{C}$ to $95^{\circ} \mathrm{C}$ (ct-DNA, rate $0.2-0.5^{\circ} \mathrm{C}$ $\mathrm{min}^{-1}$ ) or from $5^{\circ} \mathrm{C}$ to $\mathrm{ca} .60^{\circ} \mathrm{C}$ (oligonucleotides, rate $0.5-1{ }^{\circ} \mathrm{C} \mathrm{min}-1$ ). For +UV conditions the cell containing the sample was placed in a LUMOS 43 from atlas-photonics and was irradiated for $1 \mathrm{~min}$ at $360 \mathrm{~nm}$. Different Melting curves are presented as graphs of normalized absorption changes versus the temperature, and the melting temperature was obtained by fitting the curves with a sigmoidal function.

Circular Dichroism (CD). Circular dichroism spectra were recorded using a Chirascan CDspectrometer (Applied Photophysics). Before the measurement, the CD spectrum of the buffer was recorded and was automatically subtracted from the spectra of the samples with the implemented software. The samples $\left(\mathrm{C}_{\mathrm{DNA}}=50 \mu \mathrm{M}\right.$ in $10 \mathrm{mM}$ phosphate buffer, $p H=7.0$; 
ligand-DNA ratio $0,0.5$ and 2.0$)$ were measured in a quartz cell $(d=10 \mathrm{~mm})$ at $20{ }^{\circ} \mathrm{C}$ at 220 $550 \mathrm{~nm}$ (speed $=1 \mathrm{~nm} \mathrm{~s}^{-1}$, time per point $=0.5 \mathrm{~s}$ ). The spectrum of each sample was recorded two times and averaged with the implemented software.

\section{Linear Dichroism (LD).}

Linear dichroism (LD) spectra were recorded with a Chirascan spectropolarimeter (Applied Photophysics) equipped with High Shear Couette Cell Accessory. The samples ( $C_{D N A}=50 \mu M$ in $10 \mathrm{mM}$ phosphate buffer, $p H=7.0$; ligand-DNA ratio $0,0.5$ and 2.0) were oriented in a rotating couette with a shear gradient of $1200 \mathrm{~s}^{-1}$. The data were analyzed according to literature protocol. ${ }^{[1]}$

FRET measurements. A self-complementary oligonucleotide (Oligo3) labeled at its extremities by a pair of fluorophores engaged in Föster resonant energy transfer (FRET) was used for these experiments: having a fluorescein as donor (D), and Texas Red as acceptor (A) of energy. Samples containing $1 \mu \mathrm{M}$ Oligo $3(33 \mu \mathrm{M}$ in bases) in $10 \mathrm{mM}$ Tris buffer and $50 \mathrm{mM}$ $\mathrm{NaCl}$ with or without $33 \mu \mathrm{M}$ of PGD were assembled on ice. Then, samples were equilibrated at a given temperature, irradiated at $365 \mathrm{~nm}\left(10 \mathrm{~mW} . \mathrm{cm}^{-2}\right)$ if necessary and fluorescence intensities of donor $\left(I_{D}\right)$ and acceptor $\left(I_{A}\right)$ were recorded at $528 \mathrm{~nm}$ and $645 \mathrm{~nm}$ respectively upon excitation at $485 \mathrm{~nm}$ using a microplate reader (Synergy HT from BioTek with Gene5 interface). FRET efficiency $\left(E_{F R E T}\right)$ was then calculated according to the Equation S1.

$$
E_{F R E T}=\frac{I_{A}}{I_{A}+I_{D}}
$$

Fluorescence Microscopy Imaging. For fluorescence microscopy imaging, a Zeiss (Axio Observer Z1) inverted microscope equipped with a 100× oil-immersed objective and a filter set 44 (Excitation BP 475/40; Emission BP 530/50 nm) was used. Images were recorded with an EM-CCD camera (Photonmax 512B, Princeton Scientific) that was controlled with the Metavue image acquisition software (Molecular Devices). The sample was prepared by mixing $\mathrm{H}_{2} \mathrm{O}$, Tris buffer $\left(C_{\text {final }}=10 \mathrm{mM}, \mathrm{pH} 7.4\right)$, AzoGua and YOYO-1 iodide $\left(C_{\text {final }}=0.01 \mu \mathrm{M}\right)$ in this order. T4DNA ( $C_{\text {final }}=0.1 \mu \mathrm{M}$ in phosphate groups) was then added and the mixture was homogenized by gentle upside down turning. After an equilibration time of ca. $10 \mathrm{~min}, 20 \mu \mathrm{l}$ droplets were placed on a clean glass slide and were visualized by fluorescence microscopy. For each AzoGua concentration, a minimum of 150 individual DNA molecules were analyzed to determine the fraction of DNA molecules in the fully compact state (SI Figure S3b).

Static Light Scattering. Static light scattering was measured with a Brookhaven system working with a laser (output power $30 \mathrm{~mW}$ ) at $637 \mathrm{~nm}$. The data were collected at a 
temperature of $25^{\circ} \mathrm{C}$ and an angle of $90^{\circ}$. Samples were prepared by mixing ct-DNA ( $c_{\text {final }}=$ $20 \mu \mathrm{M}$ in phosphate groups), Tris buffer $\left(c_{\text {final }}=10 \mathrm{mM}, \mathrm{pH} 7.4\right)$, water and the appropriate PGD. The sample $(V=1 \mathrm{~mL})$ was placed in a micro test-tube and the scattered light of each sample was acquired for 1 min three times. 


\section{3) Synthesis of PGDs: AzoGua and AzoDiGua}

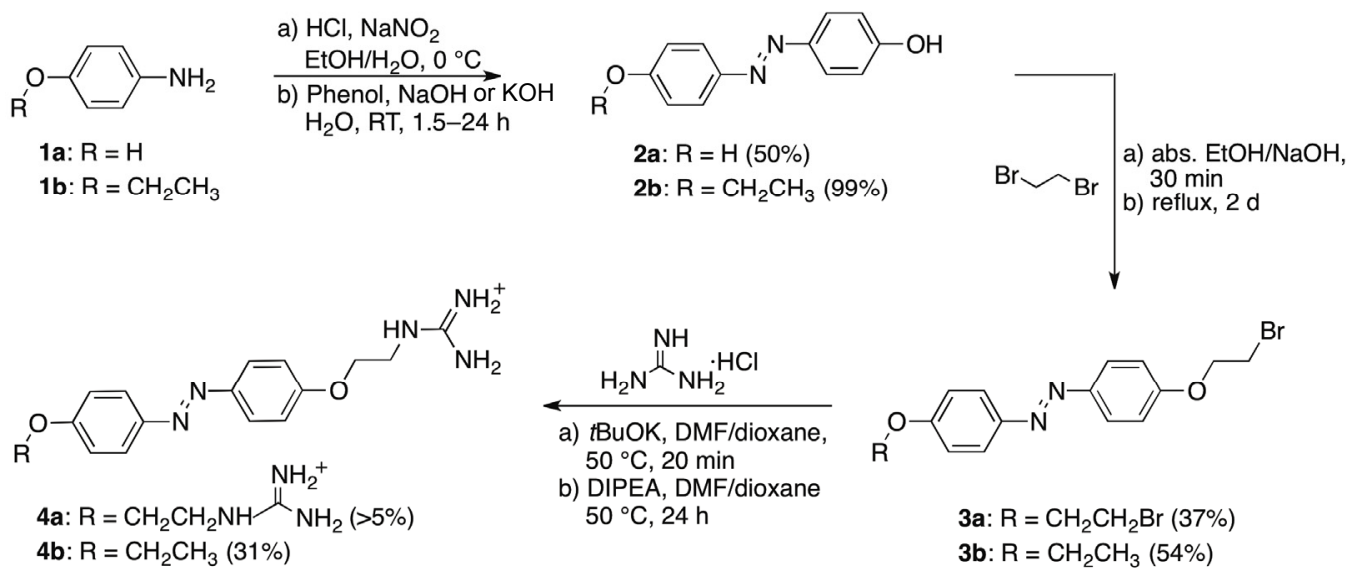

Scheme S1. Synthesis of photosensitive guanidinium derivatives (PGDs).

\section{Brief description of the synthetic route:}

AzoDiOH (2a) was synthesized by the azo coupling reaction of $p$-aminophenol and phenol with a yield of $50 \%$ (Scheme S1). After nucleophilic substitution with dibromoethane the derivative AzoDiBr (3a) was obtained as a brown powder (37\%). Treatment of AzoDiBr with guanidinium hydrochloride finally led to the azo diguanidium derivative AzoDiGua (4a). A small part of the crude product AzoDiGua was purified by HPLC and was identified and fully characterized by NMR spectroscopy, mass spectrometry and elemental analysis. The azo derivative AzoGua (4b) was synthesized in a similar way, using ethoxyaniline as the starting material instead of $p$-aminophenol to obtain the monoguanidinium derivative by the reaction of AzoBr with guanidine hydrochloride (Scheme S1). AzoGua was identified and fully characterized by NMR spectroscopy, mass spectrometry and elemental analysis.

\section{4,4'-(1,2-diazenediyl)bisphenol (AzoDiOH, 2a) ${ }^{[2]}$}

p-Aminophenol 1a (3.00 g, $27.5 \mathrm{mmol})$ was dissolved in diluted aq. $\mathrm{HCl}(35 \mathrm{ml}, 1 \mathrm{M})$ and cooled to $0{ }^{\circ} \mathrm{C}$. Subsequently an aqueous solution of $\mathrm{NaNO}_{2}(2.88 \mathrm{~g}, 41.8 \mathrm{mmol})$ was added dropwise and the resulting mixture was diluted with methanol $(100 \mathrm{~mL})$. A suspension of phenol $(2.86 \mathrm{~g}$, $30.4 \mathrm{mmol})$ and $\mathrm{KOH}(3.10 \mathrm{~g}, 55.4 \mathrm{mmol})$ in methanol $(48 \mathrm{~mL})$ that was cooled to $0{ }^{\circ} \mathrm{C}$ was added slowly and the reaction mixture was stirred for $24 \mathrm{~h}$ at room temperature. After the addition of $\mathrm{HCl}(30 \mathrm{~mL})$ and partial removal of the solvent the resulting brown precipitate was filtered, dried in vacuo and crystallized from ethanol $(2.90 \mathrm{~g}, 13.8 \mathrm{mmol}, 50 \%) .{ }^{1} \mathrm{H}-\mathrm{NMR}$ (DMSO-d $\left.d_{6}, 300 \mathrm{MHz}\right): \delta=6.90\left(\mathrm{~d},{ }^{3} \mathrm{~J}=9 \mathrm{~Hz}, 4 \mathrm{H}, \mathrm{Ar}-\mathrm{H}\right), 7.71\left(\mathrm{~d},{ }^{3} \mathrm{~J}=9 \mathrm{~Hz}, 4 \mathrm{H}, \mathrm{Ar}-\mathrm{H}\right), 10.1$ (broad s, 4H, OH). 


\section{1,2-bis[4-(2-bromoethoxy)phenyl]diazene (AzoDiBr, 3a) ${ }^{[3]}$}

To a solution of 1,2-dibromoethane $(18.0 \mathrm{~g}, 96.0 \mathrm{mmol})$ in ethanol $(5 \mathrm{~mL})$ was added dropwise within $1 \mathrm{~h}$ a solution of AzoDiOH 2a $(3.43 \mathrm{~g}, 16 \mathrm{mmol})$ and $\mathrm{NaOH}(1.54 \mathrm{~g}, 38.4 \mathrm{mmol})$ in ethanol $(85 \mathrm{~mL})$ and the resulting reaction mixture was stirred under reflux for additional $48 \mathrm{~h}$. The solution was concentrated in vacuo, the dark precipitate was filtered off and dried in vacuo (2.52 mg, $5.89 \mathrm{mmol}, 37 \%)$. ${ }^{1} \mathrm{H}-\mathrm{NMR}\left(\mathrm{CDCl}_{3}, 300 \mathrm{MHz}\right): \delta=3.68\left(\mathrm{t},{ }^{3} \mathrm{~J}=7 \mathrm{~Hz}, 4 \mathrm{H}, \mathrm{CH}_{2}\right), 4.38$ (t, $\left.{ }^{3} \mathrm{~J}=7 \mathrm{~Hz}, 4 \mathrm{H}, \mathrm{CH}_{2}\right), 7.00-7.03(\mathrm{~m}, 4 \mathrm{H}, \mathrm{Ar}-\mathrm{H}), 7.80-7.88(\mathrm{~m}, 4 \mathrm{H}, \mathrm{Ar}-\mathrm{H})$.

\section{1,1'-((1,2-diazenediyl-bis(4,1-phenylene))bis(oxy))bis(2,1-ethanediyl))diguanidinium ditrifluoracetate (AzoDiGua, 4a) ${ }^{[4]}$}

To a suspension of $t$ BuOK $(764 \mathrm{mg}, 6.81 \mathrm{mmol})$ in dioxane/DMF $(1: 1,46 \mathrm{~mL})$ was added guanidine hydrochloride $(650 \mathrm{mg}, 6.81 \mathrm{mmol})$, the mixture was stirred for $30 \mathrm{~min}$ at $50{ }^{\circ} \mathrm{C}$, filtered off and washed with dioxane/DMF (1:1, $5 \mathrm{~mL}$ ). A suspension of AzoDiBr 3a (972 mg, $2.03 \mathrm{mmol}$ ) and $N, N$-diisopropylamine (DIPEA, $890 \mu \mathrm{l}, 6.81 \mathrm{mmol}$ ) in DMF was added and the reaction mixture was stirred $2 \mathrm{~d}$ at $60{ }^{\circ} \mathrm{C}$. Afterwards the solvent was removed under reduced pressure, the remaining solid was dissolved in water and washed with $\mathrm{CH}_{2} \mathrm{Cl}_{2}$. The water was carefully removed in vacuo (caution: foaming) and a small part of the crude product was purified by preparative HPLC $\left(85-70 \% \mathrm{H}_{2} \mathrm{O} / 15-30 \% \mathrm{MeCN} / 0.1 \%\right.$ TFA, $7.8 \mathrm{~min}$; analytically pure $42.0 \mathrm{mg}, 65.6 \mu \mathrm{mol}) .{ }^{1} \mathrm{H}-\mathrm{NMR}\left(\mathrm{CD}_{3} \mathrm{OD}, 300 \mathrm{MHz}\right): \delta=3.67$ (t, $\left.{ }^{3} \mathrm{~J}=5 \mathrm{~Hz}, 4 \mathrm{H}, \mathrm{CH}_{2}\right), 4.24$ $\left(\mathrm{t},{ }^{3} \mathrm{~J}=5 \mathrm{~Hz}, 4 \mathrm{H}, \mathrm{CH}_{2}\right), 7.12\left(\mathrm{~d},{ }^{3} \mathrm{~J}=9 \mathrm{~Hz}, 4 \mathrm{H}, \mathrm{Ar}-\mathrm{H}\right), 7.87$ (d, $\left.{ }^{3} \mathrm{~J}=9 \mathrm{~Hz}, 4 \mathrm{H}, \mathrm{Ar}-\mathrm{H}\right) .{ }^{13} \mathrm{C}-\mathrm{NMR}$ $\left(\mathrm{CDCl}_{3}, 75 \mathrm{MHz}\right): \delta=42.2\left(\mathrm{CH}_{2}\right), 67.8\left(\mathrm{CH}_{2}\right), 116.0(\mathrm{CH}), 125.4(\mathrm{CH}), 148.7\left(\mathrm{C}_{\mathrm{q}}\right), 159.2\left(\mathrm{C}_{\mathrm{q}}\right)$, $162.0\left(\mathrm{C}_{\mathrm{q}}\right)$. - El. Anal. for $\mathrm{C}_{18} \mathrm{H}_{24} \mathrm{~N}_{8} \mathrm{O}_{2} \times 2.25$ TFA (640 g/mol): calculated (\%) C 42.18, $\mathrm{H} 4.09$, N 17.49; found (\%) C 42.24, H 4.14, N 17.07. - MS (ESI): m/z (\%) = 343 (100), 385 (45) [M$\mathrm{H}]^{+}$.

\section{4-[2-(4-ethoxyphenyl)diazenyl]phenol (AzoOH, 2b) ${ }^{[5]}$}

To $p$-ethoxyaniline $1 \mathrm{~b}(11.0 \mathrm{~g}, 80.0 \mathrm{mmol})$ and $\mathrm{NaNO}_{2}(5.52 \mathrm{~g}, 80 \mathrm{mmol})$ in ethanol/water (160 $\mathrm{mL}, 1: 1)$, conc. $\mathrm{HCl}(17 \mathrm{~mL})$ and ice $(80 \mathrm{~g})$ was added at $0{ }^{\circ} \mathrm{C}$. Subsequently, phenol $(7.53 \mathrm{~g}$, $80.0 \mathrm{mmol})$ and $\mathrm{NaOH}(6.40 \mathrm{~g}, 160 \mathrm{mmol})$ in cold water were added dropwise to the solution. After the reaction mixture was stirred for additional $90 \mathrm{~min}$ the $\mathrm{pH}$ was adjusted to 1 with conc. $\mathrm{HCl}$ and left to stand for $30 \mathrm{~min}$. The resulting brown precipitate was filtered off and crystallized from ethanol (18.1 g, $79.3 \mathrm{mmol}, 99 \%) .{ }^{1} \mathrm{H}-\mathrm{NMR}\left(\mathrm{CDCl}_{3}, 300 \mathrm{MHz}\right): \delta=1.45\left(\mathrm{t},{ }^{3} \mathrm{~J}=7 \mathrm{~Hz}, 3 \mathrm{H}\right.$, $\left.\mathrm{CH}_{3}\right), 4.11$ (q, $\left.{ }^{3} \mathrm{~J}=7 \mathrm{~Hz}, 2 \mathrm{H}, \mathrm{CH}_{2}\right), 6.90-7.00(\mathrm{~m}, 4 \mathrm{H}, \mathrm{Ar}-\mathrm{H}), 7.90(\mathrm{~m}, 4 \mathrm{H}, \mathrm{Ar}-\mathrm{H})$.

\section{1-[4-(2-bromoethoxy)phenyl]-2-(4-ethoxyphenyl)diazene (AzoBr, 3b)}

To a solution of 1,2-dibromoethane $(6.99 \mathrm{~g}, 37.2 \mathrm{mmol})$ in ethanol $(27 \mathrm{~mL})$ was added dropwise within $1 \mathrm{~h}$ a suspension of AzoOH $2 \mathrm{~b}$ (3.00 g, $12.4 \mathrm{mmol})$ and $\mathrm{NaOH}(620 \mathrm{mg}, 15.5 \mathrm{mmol})$ in 
ethanol $(62 \mathrm{~mL})$ and the resulting reaction mixture was stirred under reflux for $14 \mathrm{~h}$. The solution was concentrated in vacuo, the dark precipitate was filtered off and dried $(2.32 \mathrm{mg}$, $6.44 \mathrm{mmol}, 54 \%) .{ }^{1} \mathrm{H}-\mathrm{NMR}\left(\mathrm{CDCl}_{3}, 300 \mathrm{MHz}\right): \delta=1.38\left(\mathrm{t},{ }^{3} \mathrm{~J}=7 \mathrm{~Hz}, 3 \mathrm{H}, \mathrm{CH}_{3}\right), 3.61\left(\mathrm{t},{ }^{3} \mathrm{~J}=6\right.$ $\mathrm{Hz}, 2 \mathrm{H}, \mathrm{CH}_{2}$ ), 4.04 (q, $\left.{ }^{3} \mathrm{~J}=7 \mathrm{~Hz}, 2 \mathrm{H}, \mathrm{CH}_{2}\right), 4.30\left(\mathrm{t},{ }^{3} \mathrm{~J}=6 \mathrm{~Hz}, 2 \mathrm{H}, \mathrm{CH}_{2}\right), 6.91-6.97(\mathrm{~m}, 4 \mathrm{H}, \mathrm{Ar}-$ $\mathrm{H}), 7.89-7.82(\mathrm{~m}, 4 \mathrm{H}, \mathrm{Ar}-\mathrm{H})$.

\section{1-(2-(4-[(4-ethoxyphenyl)diazenyl]phenoxy)ethyl)guanidinium chloride (AzoGua, 4b) ${ }^{[4]}$}

To a suspension of $t$ BuOK (160 mg, $1.43 \mathrm{mmol}$ ) in dioxane/DMF $(1: 1,10 \mathrm{~mL}$ ) was added guanidine hydrochloride (138 mg, $1.43 \mathrm{mmol}$ ), the mixture was stirred for $20 \mathrm{~min}$ at $50{ }^{\circ} \mathrm{C}$ and filtered. The solution was treated with a suspension of $\mathbf{A z o B r} \mathbf{3 b}(250 \mathrm{mg}, 715 \mu \mathrm{mol})$ and DIPEA $(250 \mu \mathrm{l}, 1.43 \mathrm{mmol})$ in DMF and the reaction mixture was stirred $20 \mathrm{~h}$ at $50{ }^{\circ} \mathrm{C}$. Afterwards the solvent was removed under reduced pressure and the remaining solid was dissolved in acetone. After addition of a few drops of conc. $\mathrm{HCl}$ the red solution was allowed to stand for a few minutes until a precipitate was formed. After filtration and drying in vacuo of the precipitate, AzoGua 4b was obtained as a red solid (analytically pure $89.0 \mathrm{mg}, 220 \mu \mathrm{mol}$, 31\%). ${ }^{1} \mathrm{H}-\mathrm{NMR}\left(\mathrm{CD}_{3} \mathrm{OD}, 300 \mathrm{MHz}\right): \delta=1.43\left(\mathrm{t},{ }^{3} \mathrm{~J}=7 \mathrm{~Hz}, 3 \mathrm{H}, \mathrm{CH}_{3}\right), 3.66\left(\mathrm{t},{ }^{3} \mathrm{~J}=5 \mathrm{~Hz}, 2 \mathrm{H}\right.$, $\mathrm{CH}_{2}$ ), $4.13\left(\mathrm{q},{ }^{3} \mathrm{~J}=7 \mathrm{~Hz}, 2 \mathrm{H}, \mathrm{CH}_{2}\right), 4.22\left(\mathrm{t},{ }^{3} \mathrm{~J}=5 \mathrm{~Hz}, 2 \mathrm{H}, \mathrm{CH}_{2}\right), 7.04\left(\mathrm{~d},{ }^{3} \mathrm{~J}=9 \mathrm{~Hz}, 2 \mathrm{H}, \mathrm{Ar}-\mathrm{H}\right)$, $7.11\left(\mathrm{~d},{ }^{3} \mathrm{~J}=9 \mathrm{~Hz}, 2 \mathrm{H}, \mathrm{Ar}-\mathrm{H}\right), 7.84\left(\mathrm{~d},{ }^{3} \mathrm{~J}=9 \mathrm{~Hz}, 2 \mathrm{H}, \mathrm{Ar}-\mathrm{H}\right), 7.87\left(\mathrm{~d},{ }^{3} \mathrm{~J}=9 \mathrm{~Hz}, 2 \mathrm{H}, \mathrm{Ar}-\mathrm{H}\right) .{ }^{13} \mathrm{C}-$ $\operatorname{NMR}\left(\mathrm{CDCl}_{3}, 75 \mathrm{MHz}\right): \delta=15.1\left(\mathrm{CH}_{3}\right), 42.1\left(\mathrm{CH}_{2}\right), 64.9\left(\mathrm{CH}_{2}\right), 67.7\left(\mathrm{CH}_{2}\right), 115.8(\mathrm{CH}), 115.9$ $(\mathrm{CH}), 125.3(\mathrm{CH}), 125.5(\mathrm{CH}), 148.1\left(\mathrm{C}_{\mathrm{q}}\right), 148.7\left(\mathrm{C}_{\mathrm{q}}\right), 159.0\left(\mathrm{C}_{\mathrm{q}}\right), 161.8\left(\mathrm{C}_{\mathrm{q}}\right), 162.8\left(\mathrm{C}_{\mathrm{q}}\right) .-\mathrm{El}$. Anal. for $\mathrm{C}_{17} \mathrm{H}_{21} \mathrm{~N}_{5} \mathrm{O}_{2} \times 2 \mathrm{HCl} \times 0.5 \mathrm{H}_{2} \mathrm{O}(408 \mathrm{~g} / \mathrm{mol})$ : calculated (\%) C 49.88, $\mathrm{H}$ 5.91, N 17.11; found (\%) C 49.78, H 5.64, N 16.76. - MS (ESI): $\mathrm{m} / \mathrm{z}(\%)=328(100)[\mathrm{M}-\mathrm{H}]^{+}$.

\section{Analysis}

NMR spectroscopy: Spectra were recorded on a Bruker spectrometer (300 MHz). As internal standard the residual solvent protons $\left({ }^{1} \mathrm{H}\right)$ or carbons $\left({ }^{13} \mathrm{C}\right)$ were used.

Mass Spectrometry: Spectra were measured by the Ecole Nationale Superieure de Chimie de Paris mass spectrometry services laboratory.

Elemental Analysis: CHN analysis were performed by the Microanalysis of ICSN CNRS. 


\section{4) Thermal relaxation of AzoGua and AzoDiGua}
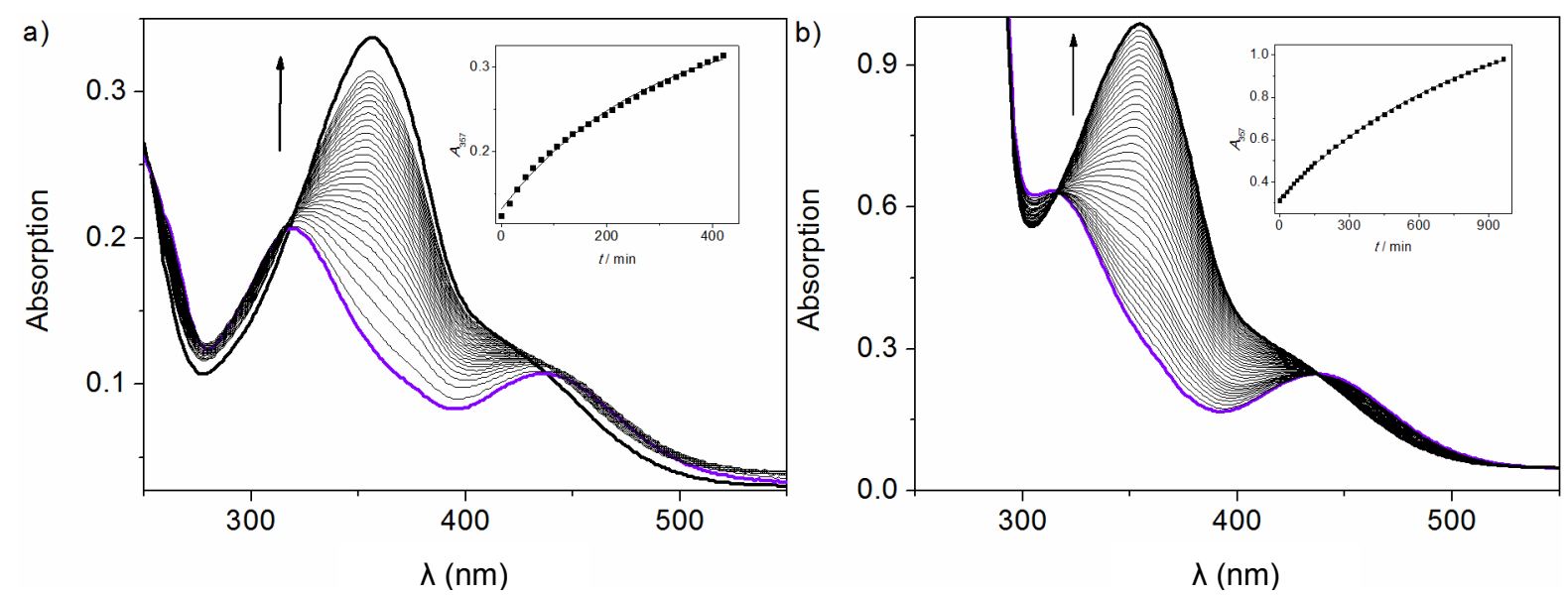

Figure S1. Absorption spectra of AzoGua [31.6 $\mu \mathrm{M}$ in $\mathrm{H}_{2} \mathrm{O}(\mathrm{a})$ ] and AzoDiGua [100 $\mu \mathrm{M}$ in $\mathrm{H}_{2} \mathrm{O}$ (b)] after initial UV irradiation at $365 \mathrm{~nm}$ for $4 \mathrm{~min}$ (purple curve), acquired at $26{ }^{\circ} \mathrm{C}$ at time intervals of 15-30 min (black curves). Inset: absorption at $357 \mathrm{~nm}$ as a function of time. The solid line is an exponential fit providing a characteristic thermal relaxation time of $280 \mathrm{~min}$ and 824 min for AzoGua and AzoDiGua, respectively.

\section{UV spectroscopic kinetic studies:}

Experimental data of trans-cis (Figure 2a, b) and cis-trans (SI Figure S1) isomerization were fitted to the exponential Equation S2 $\left(r^{2}>0.99\right)$.

$$
y=A e^{-\frac{x}{t}}+y_{0}
$$

$\begin{array}{lllll}\text { AzoGua: } & \text { trans-cis: } A=0.36 ; & t=14.8 \mathrm{~s} ; & \mathrm{y}_{0}=0.12 & \text { (Figure 2a) } \\ \text { cis-trans: } A=-0.22 ; & t=280 \mathrm{~min} ; & \mathrm{y}_{0}=0.36 & \text { (SI Figure S1) }\end{array}$

AzoDiGua: trans-cis: $A=0.73 ; \quad t=27.2 \mathrm{~s} ; \quad \mathrm{y}_{0}=0.26 \quad$ (Figure $2 \mathrm{~b}$ )

cis-trans: $A=-0.93 ; \quad t=824 \mathrm{~min} ; \quad \mathrm{y}_{0}=1.27 \quad$ (SI Figure $\mathrm{S} 1$ ) 


\section{5) Binding of AzoDiGua to double- and single-stranded}

\section{oligonucleotides}
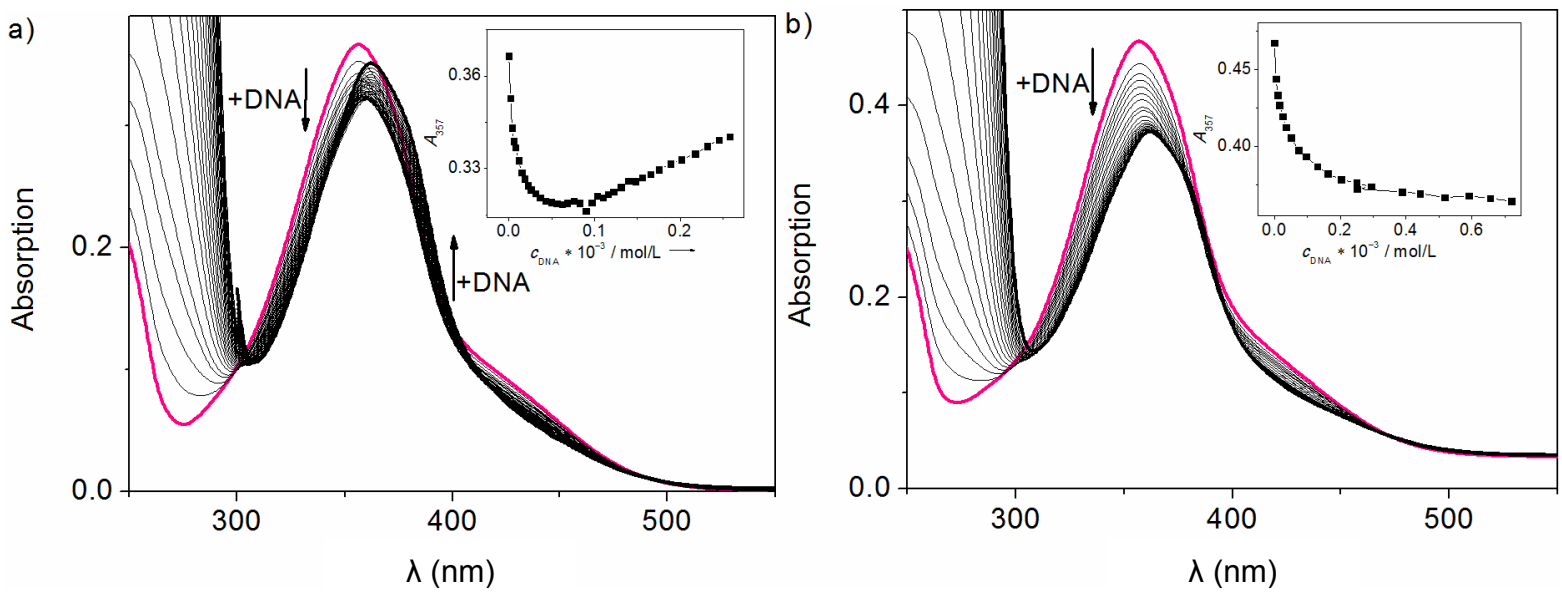

Figure S2. Absorption spectra of AzoDiGua (25 $\mu \mathrm{M}$ in Tris buffer $+10 \mathrm{mM} \mathrm{NaCl}$ ) with increasing concentration of double-stranded (a) and single-stranded (b) Oligo2. Insets show the absorption at $357 \mathrm{~nm}$ as a function of the concentration of double -stranded (a) or single stranded (b) Oligo2. Solid lines are guides for the eyes. 


\section{6) Compaction of T4DNA induced by AzoGua}

a)

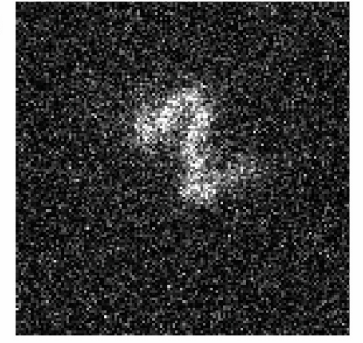

T4DNA + AzoGua $25 \mu \mathrm{M}$ "unfolded state"

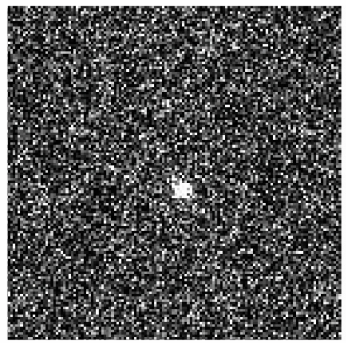

T4DNA + AzoGua $100 \mu \mathrm{M}$ "compact state"

b)

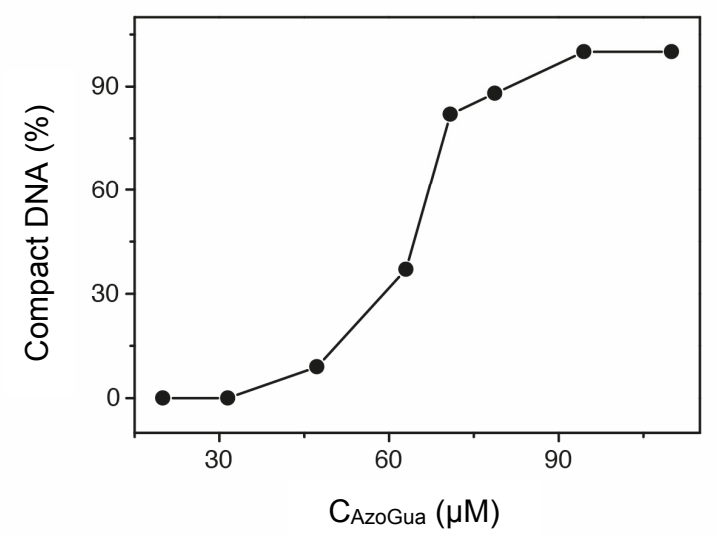

Figure S3. Fluorescence microscopy observations of T4DNA $(0.1 \mu \mathrm{M}$ in $10 \mathrm{mM}$ Tris buffer at $\mathrm{pH}$ 7.4) dyed with YOYO-1 (0.01 $\mu \mathrm{M})$. a) At a low AzoGua concentration, all DNA molecules appear as fluctuating, elongated coils attributed to the unfolded state of the DNA (left). At a high AzoGua concentration, all DNA molecules appear as bright, fast-diffusing spots attributed to the fully compact state (right). Image sizes are $13.2 \mu \mathrm{m} \times 13.2 \mu \mathrm{m}$. b) Fraction of DNA molecules in a fully compact state as a function of the concentration of AzoGua. Solid line serves as guide for the eyes. 


\section{7) Light-scattering of PGD-DNA complexes at different ratios}

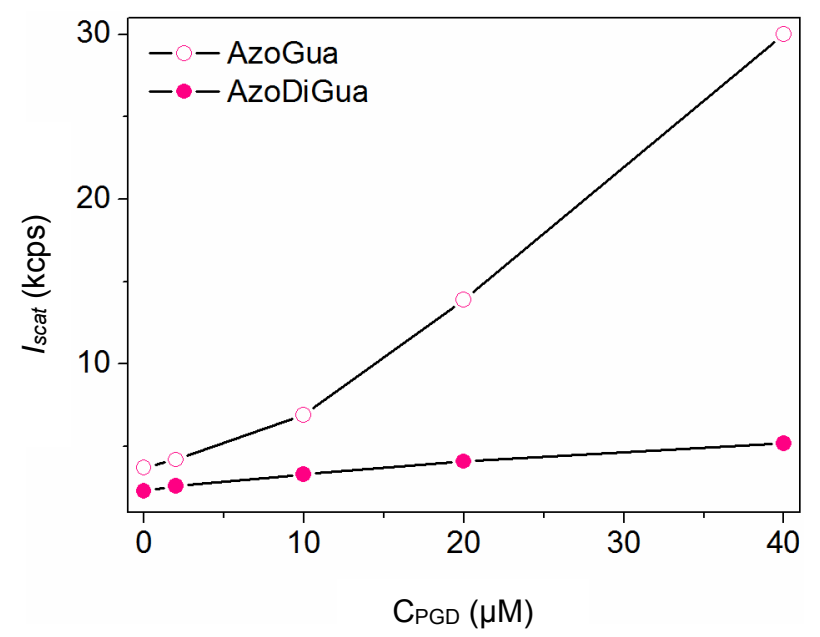

Figure S4. Static light scattering of ct-DNA (20 $\mu \mathrm{M}$ in Tris buffer) with increasing concentrations of AzoGua and AzoDiGua. Under experimental conditions of melting studies, AzoGua induces strong scattering attributed to DNA compaction (SI Figure S3), while AzoDiGua does not significantly change the scattering intensity, indicating the absence of DNA compaction in this concentration range. 


\section{8) Melting of DNA in the presence of AzoDiGua $\pm U V$}
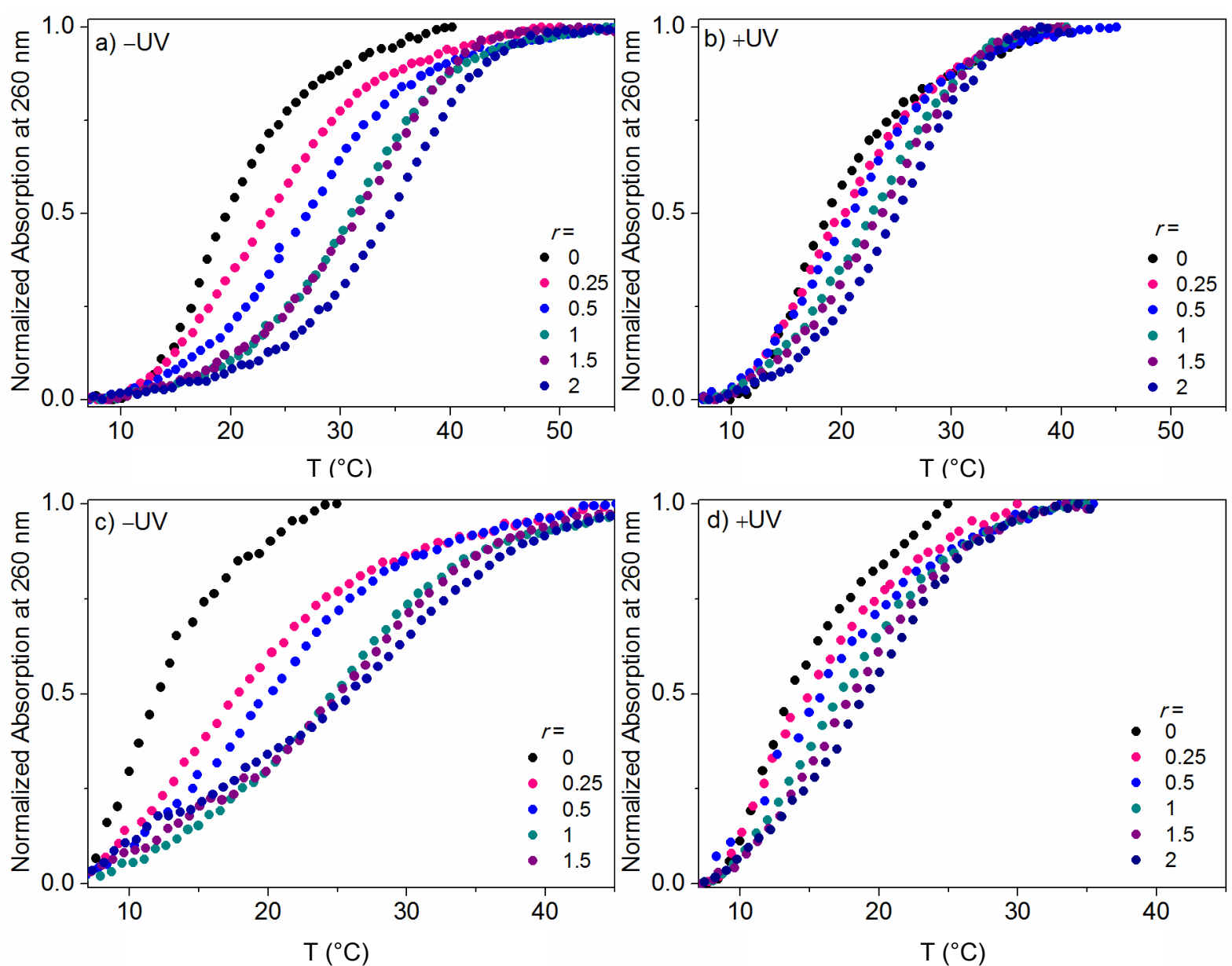

Figure S5. Thermal denaturation profiles of Oligo1 (a, b) and Oligo2 (c, d) (20 $\mu \mathrm{M}$ in Tris buffer) with increasing the AzoDiGua:DNA ratio, without $(a, c)$ and with $(b, d)$ illumination at $365 \mathrm{~nm}$ for 1 min prior to acquiring the melting curve. 


\section{9) Control experiments for the photoreversible melting of Oligo3}

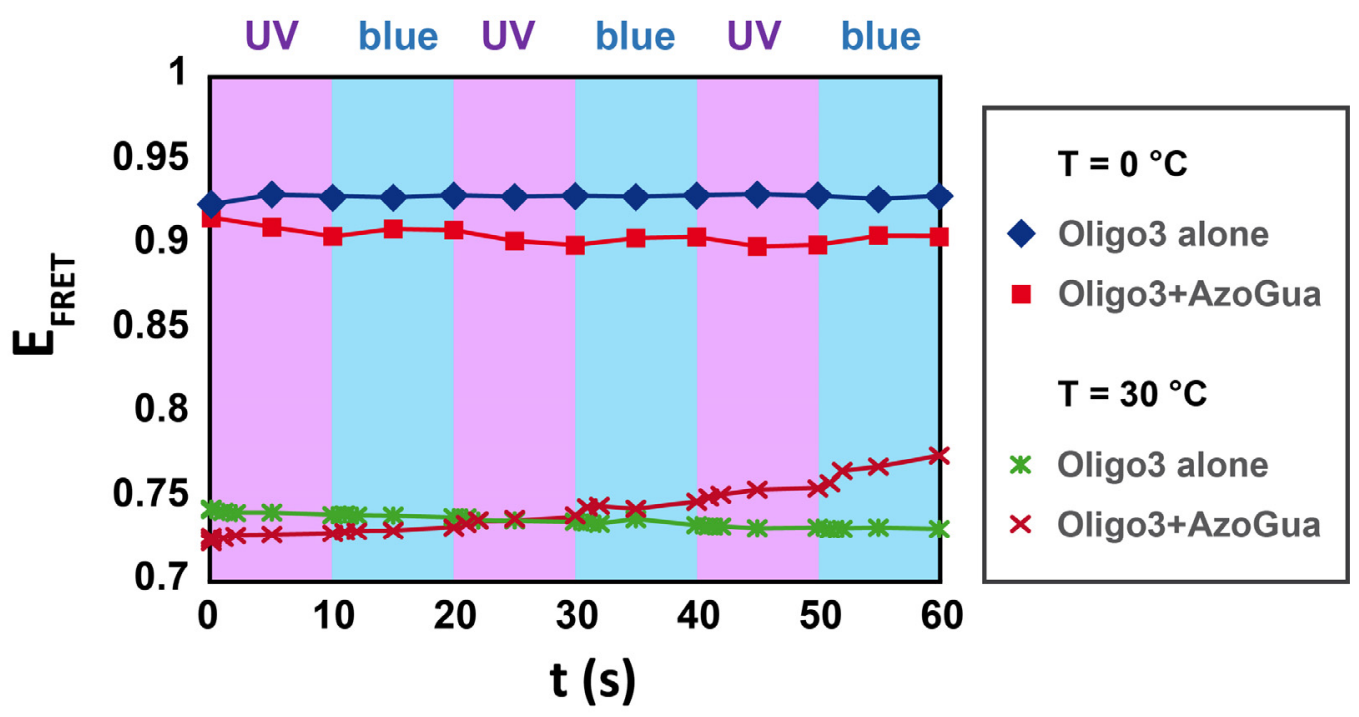

Figure S6. FRET efficiency ( $E_{F R E T}$ ) of Oligo3 with or without AzoGua, as a function of time, for successive cycles of UV (365 nm) and blue (440 nm) illumination performed at a constant temperature $\mathrm{T}=0^{\circ}$ or $30^{\circ} \mathrm{C}$. [Oligo3] $=33 \mu \mathrm{M}$ in $10 \mathrm{mM}$ Tris buffer $\mathrm{pH} 7.4+50 \mathrm{mM} \mathrm{NaCl}$; [AzoGua]:Oligo3 ratio $r=1$. 


\section{0) References}

[1] A. Granzhan, H. Ihmels, G. Viola, J. Am. Chem. Soc., 2007, 129, 1254-1267.

[2] a) N. Iyi, T. Fujita, C.V. Yelamaggad, F. Lopez Arbeleo, Applied Clay Science 2001, 19, 47-58; b) R. Klajn, K. J. M. Bishop, B. A. Grzybowski, Proc. Natl. Acad. Sci. USA 2007, 104, 10305-10309. c) F. P. Hubbard Jr., N. L. Abbott, Soft Matter, 2008, 4, $2225-$ 2231.

[3] X. Xing, X. Wang, L. Xu, Y. Tai, L. Dai, X. Zheng, W. Mao, X. Xu, X. Zhou, Org. Biomol. Chem. 2011, 9, 6639-6645.

[4] A. Bugaut, K. Jantos, J.-L. Wietor, R. Rodriguez, J. K. M. Sanders, S. Balasubramanian, Angew. Chem. Int. Ed. 2008, 47, 2677-2680.

[5] A. Diguet, N. K. Mani, M. Geoffroy, M. Sollogoub, D. Baigl, Chem. Eur. J. 2010, 16, 11890-11896. 